\title{
Customers' Choice between Online or Offline Channel about Search Products, Experience Products and Credence Products
}

\author{
Yicheng Liu ${ }^{1}$ \\ ${ }^{1}$ Department of Marketing, School of Economic and Management, Tsinghua University, Beijing, China \\ Correspondence: Yicheng Liu, Department of Marketing, School of Economic and Management, Tsinghua \\ University, Room 105B, Building \#15, Zijing Apartment, Haidian District, 100084, Beijing, China. E-mail: \\ liuych.08@sem.tsinghua.edu.cn
}

Received: September 7, 2016

doi:10.5539/ibr.v9n11p38

\author{
Accepted: September 21, $2016 \quad$ Online Published: September 23, 2016 \\ URL: http://dx.doi.org/10.5539/ibr.v9n11p38
}

\begin{abstract}
This study aims to find out customers' decisions between online or offline channel about search products, experience products and credence products. For this purpose, we analyzed 120 volunteers with 5 experiments, to verify 6 hypotheses. We summarized traditional online and offline channel theory and tried to research this topic in five aspects, which are website design, offline shop distance, customer group selection, media publicity and offline channel's help for online. According to the results of 5 experiments, we finally find out customer's choice between online and offline channel influenced by the category of products and 5 different factors. Besides, we also offer some suggestions about how to attract customers from offline channel to online channel.
\end{abstract}

Keywords: search products, experience products, credence products, online or offline, channel choice

\section{Introduction}

During the speed development of $\mathrm{O} 2 \mathrm{O}$ business, more and more customers go shopping online, instead of the tradition way. As online and offline shops become two available choices for the customers, it's necessary to know their preference between the two channels under different conditions.

The category of products is the most important element to influence customer choice between online and offline channel. As Nelson (1970, 1974), Darby and Karni (1973) said, we classify products into 3 types, search products, experience products and credence products. Every type has its own characteristic, which will lead to different shopping environment requirements for the consumers. This environment can be shopping location or interpersonal environment, like shopping alone or with friends.

This study aims to find out customers' decision between online or offline channel about search products, experience products and credence products, based on 5 influence factors. For this purpose we analyzed 120 volunteers with 5 experiments, to verify 6 hypotheses. All the hypotheses are based on 5 factors, calling website design(Chocarro and Mónica Cortinas, 2013), offline shop distance(Raquel Chocarro, Mónica Cortinas and María-Luisa Villanueva, 2013), customer group selection(Raquel Chocarro, Mónica Cortinas and María-Luisa Villanueva, 2013), media publicity(Koen Pauwels, Peter S.H. Leeflang, Marije L. Teerling and K.R. Eelko Huizingh, 2011) and offline channel's help for online(Shuiqing Yang, Yaobin Lu, Ling Zhao and Sumeet Gupta, 2011).

Previous references did research about each factor alone, but never made a general analysis about all the influence factors. Our study tries to summarize all kinds of influence factors and do some empirical test.

We have organized the remainder of this article as follows. Part 2 provides a literature review and the research background. Part 3 describes the hypotheses. Part 4 explains the experiments and methodology. Part 5 summarizes the results.

\section{Literature Review}

Nelson (1970, 1974), Darby and Karni (1973) divided products into three kinds, search products, experience products and credence products. (Tulay Girard, Paul Dion, 2010)

They defined search products as standardized products that the customers can know their quality, size, performance, style and safety without using. Wallpaper, footballs and cups are search products, because we can 
know their performance, size and style just by having a look.

Experience products are something that the customers cannot know their quality, size, performance, style and safety without using. For instance, shoes, drinks and books are known as experience products.

An experience product's quality is difficult to assess prior to purchase, largely due to the limited availability of information before consumption. (Goksel Yalcinkaya, \& Tevfik Aktekin, 2015) What's more, when consumers decide to buy an experience product, they may hesitate to make the decision because they don't know how long it takes to learn the application method. (Darron Billeter, Ajay Kalra, \& George Loewenstein, 2011)

Credence products are defined as the products that the customers can only know their quality, size, performance, style and safety after a long-term usage. In other words, they cannot know the information by short-term experience. This kind of products usually has a long life cycle. For example, insurance products, debit card service and educational training are all credence products.

Search products are naturally suitable for selling online, because the customers can know all the property without using. Online selling has a higher speed of information transmission and trading efficiency than offline.

With other conditions unchanged, experience products are suitable for offline sales. The customers can only know the quality, size, performance, style and safety after using. In other words, products usage experience is a necessary course to know its property. As a result, the consumers will be like to experience the product before buy it, which gives the offline shop an important advantage than online shop.

Credence products are very special, whose property cannot be known until being used for a long time. For this kind of products, introduction and recommendation from the service persons will be quite necessary, which can only be acquired in the offline shop.

Tobias Kollmann, Andreas Kuckertz and Ina Kayser (2012) described the different factors that will influence consumers' decision between online or offline channel.

Gila E. Fruchter and Charles S. Tapiero (2005) made a strategy about pricing of online or offline channel. Retailing pricing of online or offline channel was a popular topic, some researchers made reviews. (Dhruv Grewal, Ramkumar Janakiraman, Kirthi Kalyanam, P.K. Kannan, Brian Ratchford, Reo Song, \& Stephen Tolerico, 2010)

People also imaged the multi-channel store as a perfect sample of selling goods. (Tibert Verhagen, \& Willemijn van Dolen, 2009)

Generally speaking, when online and offline channel compete with each other, there will be 5 different factors, calling website design, offline shop distance, customer group selection, media publicity and offline channel's help for online.

Website design is an important factor to influence the customer's decision. According to the paper of Raquel Chocarro and Mónica Cortinas (2013), a simpler website layout will lead to a higher probability online shopping. For search products, this effect is very obvious. However, for experience products customers, the simplification of website layout is not that important, because consumers need to know some details about experience products. In other words, the desire for detailed information will weaken the aversion for a complex website process. Credence products are very special, which cannot be fully known by the customers only by means of internet information. As a result, credence products consumers will prefer offline channel.

Perceived website quality will have a great influence on the trust of consumers for retailers. Some introduction about products performance is important to the website quality, because it will help customers understand the products and improve online purchase. (Gee-Woo Bock, Jumin Lee, Huei-Huang Kuan and Jong-Hyun Kim, 2012)

Offline shop distance is important to the purchase choice. A long distance will decrease the possibility of customers to choose offline shop, and this phenomenon is more obvious for search products than experience products.(Raquel Chocarro, Mónica Cortinas and María-Luisa Villanueva, 2013) Consumers of experience products will need an offline shop to experience the quality of products, even if the shop is far away. Consumers of credence products need some detailed introduction from the salesmen, so they will naturally tend to offline channel. Their capacity for tolerance of distance is even better than experience products consumers and search products consumers.

Customer group selection is an interesting topic. When people go shopping with their friends or relatives, they will prefer offline channel (Raquel Chocarro, Mónica Cortinas and María-Luisa Villanueva, 2013). This effect will be more significant for experience products consumers than search products consumers. Credence products 
buyers are even more interested in offline shop than experience products buyers, because they want more products information than others. Originally, there are two kinds of people, one enjoys social contact and the other fears it. Someone chooses online shopping because of their fear of social contact. However, shopping with friends or relatives will give people familiarity feeling, which will ease the feeling of fear about social contact.

Media publicity is a popular research field. In the long term, the introduction of news internet will reduce the sales of offline shop but will increase the average sale of all goods including online or offline channel. In other words, media publicity will guide consumers to online channel, because they can acquire products information from the media. Although some of the customers turn to online channel, the total sales will be higher because the average sale of all goods increases. (Koen Pauwels, Peter S.H. Leeflang, Marije L. Teerling and K.R. Eelko Huizingh, 2011)

Internet word of mouth has a significant influence on consumers' perceived trust for the products, and bad word of mouth will have a punishment effect on products sales. The influence of word of mouth on trust will be more obvious before than after interaction with consumers. If the merchant wants to attract customers, they should keep a good product image before the interaction with them. (Gee-Woo Bock, Jumin Lee, Huei-Huang Kuan and Jong-Hyun Kim, 2012)

Online information from different group will have different influence on search products and experience buyers. For experience products buyers, online information from customers will be more important. However, for search products buyers, online information from retailers and suppliers will be more significant. Besides, the neutrality of the website will be an important factor for experience consumers. Generally speaking, if online shops want to attract customers to buy experience products, they should keep good internet word of mouth from a neutral website. (Lien-Ti Bei, Etta Y. I. Chen and Richard Widdows, 2004)

Consumers will choose a different complaint channel in an online shopping environment than in an offline shopping environment, and there will be an interaction between the purchase environment and the consumer's degree of dissatisfaction ( Seul Lee \& Brenda J. Cude, 2011)

Social media will influence the search products and experience products consumers significantly. (Jeen-Su Lim, Abdulrahman Al-Aali, \& John H. Heinrichs, 2015)

Offline channel's help for online is known as that the perceived offline service quality of customers will have a positive influence on online consumption. If consumers can feel good perceived service quality in the offline experience shop, they online consumption will increase as well. (Shuiqing Yang, Yaobin Lu, Ling Zhao and Sumeet Gupta, 2011) Customers' past shopping experience will be important to their future judgment. (Stephen J. Hoch, 2002)

\section{Hypotheses}

According to the literature part, when online and offline channel compete with each other, there will be 5 different factors, calling website design, offline shop distance, customer group selection, media publicity and offline channel's help for online.

Besides, the influence those 5 factors have on consumers' decisions will vary with different kinds of products. Search products, experience products and credence products will make a difference to the influence.

\subsection{Website Design}

According to the literature, consumers will choose simple and easy process when they buy search products. When considering the decision for experience products, complicated information and process on the website will be less disgusted, so the simplicity of website is not very important for them. Credence products consumers will be willing to accept complex process online and get more information for the products, so simplicity is also not attractive to them. (Raquel Chocarro and Mónica Cortinas, 2013)

As a result, we can make the hypothesis 1 that:

H1. The simpler the online shopping process is, the more possible the customers will use online channel.

H1a. For search products, the simpler the online shopping process is, the possibility of the customers to use online channel will be much higher.

H1b. For experience products, the simpler the online shopping process is, the possibility of the customers to use online channel will not increase significantly.

H1c. For credence products, the simpler the online shopping process is, the possibility of the customers to use online channel will not increase significantly. 


\subsection{Offline Shop Distance}

Naturally, customers will prefer offline shop in short distance. If the distance is too long, some of them will choose online channel, especially for the search products consumers who can easily know the performance and quality of products. Experience products customers are not so easy to know the information about the products, so offline shop will be convenient to get more details. Consumers for credence products will not feel a big difference between online channel and offline channel, because even if the offline shop cannot let them know the products well. (Raquel Chocarro, Mónica Cortinas and María-Luisa Villanueva, 2013)

So we can have the hypothesis 2 that:

H2. The longer the distance of the offline shop is, the more likely the customers will use online channel.

H2a. For search products, the longer the distance of the offline shop is, the possibility of the customers to use online channel will be much higher.

H2b. For experience products, the longer the distance of the offline shop is, the possibility of the customers to use online channel will not increase significantly.

H2c. For credence products, the longer the distance of the offline shop is, the possibility of the customers to use online channel will almost stay the same.

\subsection{Customer Group Selection}

Consumers are usually divided into two kinds, calling social active and social phobia consumers. Social active consumers enjoy communicating with people, so they will like offline shopping. However, social phobia consumers dislike communication, which means that they will prefer online channel.

When social active consumers and social phobia consumers make the decision of search products, experience products or credence products, their choice will not be the same. For example, shopping with friends or relatives will reduce their fear for social communication, especially for social phobia consumers, but this effect will not be quite obvious for social active consumers. (Raquel Chocarro, Mónica Cortinas and María-Luisa Villanueva, 2013)

To study the difference between two kinds of consumers when they shopping with friends or relatives, we design hypothesis 3 and hypothesis 4 :

H3. Social active consumers prefer offline channel.

H3a. For search products, when shopping with friends or relatives, the possibility of social active customers to use online channel will not change a lot.

H3b. For experience products, when shopping with friends or relatives, the possibility of social active customers to use online channel will be lower.

H3c. For credence products, when shopping with friends or relatives, the possibility of social active customers to use online channel will be even lower than experience products consumers.

H4. Social phobia consumers prefer online channel.

H4a. For search products, when shopping with friends or relatives, the possibility of social phobia customers to use online channel will be lower.

H4b. For experience products, when shopping with friends or relatives, the possibility of social phobia customers to use online channel will be even lower than search products consumers.

H4c. For credence products, when shopping with friends or relatives, the possibility of social phobia customers to use online channel will be even lower than experience products consumers.

\subsection{Media Publicity}

Internet word of mouth has a significant influence on consumers' perceived trust for the products, and bad word of mouth will have a punishment effect on products sales. Internet word of mouth is quite important, because it can leave a good impression on consumers' mind. (Gee-Woo Bock, Jumin Lee, Huei-Huang Kuan and Jong-Hyun Kim, 2012)

The neutrality of the website will be an important factor for experience consumers. (Lien-Ti Bei, Etta Y. I. Chen and Richard Widdows, 2004)

Social media will influence the search products and experience products consumers significantly. (Jeen-Su Lim, Abdulrahman Al-Aali, \& John H. Heinrichs, 2015) 
Based on the literature above, we can hypothesis 5 that:

H5. Good word of mouth and publicity from neutral media and websites will increase long-term sales of online channel.

H5a. For search products, good word of mouth and publicity from neutral media and websites will not make a big improvement in long-term sales of online channel.

H5b. For experience products, good word of mouth and publicity from neutral media and websites will make a big improvement in long-term sales of online channel.

H5c. For credence products, good word of mouth and publicity from neutral media and websites will make a big improvement in long-term sales of online channel, but the improvement will be less than in experience products.

\subsection{Offline Channel's Help for Online}

As the literature tells us, offline channel can help the online channel by a positive effect on online consumption from the perceived offline service quality of customers. If consumers can feel good perceived service quality in the offline experience shop, they online consumption will increase as well. (Shuiqing Yang, Yaobin Lu, Ling Zhao and Sumeet Gupta, 2011) Customers' past shopping experience will be important to their future judgment. (Stephen J. Hoch, 2002)

We have hypothesis 6 that:

H6. The higher the perceived offline service quality of customers is, the more likely that the customers will consume online.

H6a. For search products, the higher the perceived offline service quality of customers is, the more likely that the customers will consume online.

H6b. For experience products, the higher the perceived offline service quality of customers is, the more likely that the customers will consume online, and the possibility will be even higher than search products.

H6c. For credence products, the higher the perceived offline service quality of customers is, the possibility of customers' online consumption will not increase significantly.

\section{Experiments and Methodology}

To test the 6 hypotheses above, we design 5 experiments. We choose all the volunteers during 20-25 years old university students. About half of the volunteers are male and the other half are female. The experiments were done in December, 2015.

\subsection{Experiment 1}

Experiment 1 is a $3 \times 2$ design, to test hypothesis 1 . We chose 120 volunteers, who were divided into 6 teams, each with 20 volunteers. Then we let them shop on two designed websites, one is a simple and direct shopping website, the other is a complicated website including a lot of products information before shopping.

60 volunteers used the first website, the other 60 volunteers used another. One third of each 60 volunteers would buy search products, one third would buy experience products, and the last one third would choose credence products. The result of the 6 teams is shown below:

Table 1. Experiment 1 design

\begin{tabular}{ll}
\hline A:Search products, direct shopping & $\begin{array}{l}\text { B:Search products, reading complicated introduction before } \\
\text { shopping }\end{array}$ \\
\hline C:Experience products, direct shopping & $\begin{array}{l}\text { D:Experience products, reading complicated introduction } \\
\text { before shopping } \\
\text { F:Credence products, reading complicated introduction } \\
\text { before shopping }\end{array}$ \\
\hline
\end{tabular}

By comparing team A and team B, team C and team D, team E and team F, we can see the differences of the possibility of shopping online or offline, then we can test hypothesis 1 .

By comparing the difference of the possibility of shopping online or offline in team A and team B, we can test hypothesis $1 \mathrm{a}$.

By comparing the difference of the possibility of shopping online or offline in team C and team D, we can test hypothesis $1 \mathrm{~b}$. 
By comparing the difference of the possibility of shopping online or offline in team E and team F, we can test hypothesis 1c.

\subsection{Experiment 2}

Experiment 2 is a $3 \times 2$ design, to test hypothesis 2 . We chose 120 volunteers, who were divided into 6 teams, each with 20 volunteers. Then we let them choose online or offline channel to buy products. The online channel is a simple website, on which you could consume directly. Half of the volunteers were told that the offline shop was quite far away, while the other half of the volunteers were given a short-distance shop. One third of each 60 volunteers would buy search products, one third would buy experience products, and the last one third would choose credence products. The result of the 6 teams is shown below:

Table 2. Experiment 2 design

\begin{tabular}{ll}
\hline A:Search products, nearby offline shop & B:Search products, long distance offline shop \\
\hline C:Experience products, nearby offline shop & D:Experience products, long distance offline shop \\
E:Credence products, nearby offline shop & F:Credence products, long distance offline shop \\
\hline
\end{tabular}

By comparing team A and team B, team C and team D, team E and team F, we can see the differences of the possibility of shopping online or offline, then we can test hypothesis 2 .

By comparing the difference of the possibility of shopping online or offline in team A and team B, we can test hypothesis 2a.

By comparing the difference of the possibility of shopping online or offline in team C and team D, we can test hypothesis $2 b$.

By comparing the difference of the possibility of shopping online or offline in team $\mathrm{E}$ and team $\mathrm{F}$, we can test hypothesis 2c.

\subsection{Experiment 3}

Experiment 3 is a $3 \times 2 \times 2$ design, to test hypothesis 3 and hypothesis 4 . We chose 120 volunteers, who were divided into 12 teams, each with 10 volunteers. Then we let them choose online or offline channel to buy products. Half of them are social active consumers and half are social phobia consumers. One third of each 60 volunteers would buy search products, one third would buy experience products, and the last one third would choose credence products. Every kind of consumers for search products, experience products and credence products was divided into 2 parts, one made decisions alone, the other went shopping with their friends or relatives. The result of the 12 teams is shown below:

Table 3. Experiment 3 design

\begin{tabular}{llll}
\hline $\begin{array}{l}\text { A: Social active, } \\
\text { search products, shopping } \\
\text { alone }\end{array}$ & $\begin{array}{l}\text { D: Social active, } \\
\text { search products, shopping } \\
\text { with friends or relatives }\end{array}$ & $\begin{array}{l}\text { G:Social phobia, search } \\
\text { products, shopping alone }\end{array}$ & $\begin{array}{l}\text { J: Social phobia, } \\
\text { search products, shopping } \\
\text { with friends or relatives }\end{array}$ \\
\hline $\begin{array}{l}\text { B:Social active, experience } \\
\text { products, shopping alone }\end{array}$ & $\begin{array}{l}\text { E:Social active, experience } \\
\text { products, shopping with } \\
\text { friends or relatives }\end{array}$ & $\begin{array}{l}\text { H:Social phobia, experience } \\
\text { products, shopping alone }\end{array}$ & $\begin{array}{l}\text { K:Social phobia, experience } \\
\text { products, shopping with } \\
\text { friends or relatives }\end{array}$ \\
$\begin{array}{l}\text { C:Social active, credence } \\
\text { products, shopping alone }\end{array}$ & $\begin{array}{l}\text { F:Social active, credence } \\
\text { products, shopping with } \\
\text { friends or relatives }\end{array}$ & $\begin{array}{l}\text { I:Social phobia, credence } \\
\text { products, shopping alone }\end{array}$ & $\begin{array}{l}\text { L:Social phobia, credence } \\
\text { products, shopping with } \\
\text { friends or relatives }\end{array}$ \\
\hline
\end{tabular}

By comparing team A and team $\mathrm{G}$, team B and team $\mathrm{H}$, team $\mathrm{C}$ and team I, team $\mathrm{D}$ and team J, team $\mathrm{E}$ and team $\mathrm{K}$, team $\mathrm{F}$ and team $\mathrm{L}$, we can see the differences of the possibility of shopping online or offline, then we can test hypothesis 3.

By comparing the difference of the possibility of shopping online or offline in team A and team D, we can test hypothesis 3 a.

By comparing the difference of the possibility of shopping online or offline in team B and team E, we can test hypothesis $3 \mathrm{~b}$.

By comparing the difference of the possibility of shopping online or offline in team C and team $\mathrm{F}$, we can test hypothesis $3 c$.

By comparing team A and team G, team B and team H, team C and team I, team D and team J, team E and team $\mathrm{K}$, team $\mathrm{F}$ and team $\mathrm{L}$, we can see the differences of the possibility of shopping online or offline, then we can test hypothesis 4.

By comparing the difference of the possibility of shopping online or offline in team $\mathrm{G}$ and team $\mathrm{J}$, we can test hypothesis 4a. 
By comparing the difference of the possibility of shopping online or offline in team $\mathrm{H}$ and team $\mathrm{K}$, we can test hypothesis $4 \mathrm{~b}$.

By comparing the difference of the possibility of shopping online or offline in team I and team L, we can test hypothesis 4c.

\subsection{Experiment 4}

Experiment 4 is a $3 \times 2 \times 2$ design, to test hypothesis 5 . We chose 120 volunteers, who were divided into 12 teams, each with 10 volunteers. One third of each 60 volunteers would buy search products, one third would buy experience products, and the last one third would choose credence products. All the consumption behaviors were online, which would be influenced by good word of mouth and publicity from neutral media and websites. The result of the 12 teams is shown below:

Table 4. Experiment 4 design

\begin{tabular}{|c|c|c|c|c|c|}
\hline $\begin{array}{l}\text { A:Search } \\
\text { products, } \\
\text { no publicity, no }\end{array}$ & $\begin{array}{l}\text { B:Search } \\
\text { products, } \\
\text { no publicity, } \\
\text { good word of } \\
\text { mouth }\end{array}$ & $\begin{array}{l}\text { rience } \\
\text { s, } \\
\text { icity, } \\
\text { d of mouth }\end{array}$ & $\begin{array}{l}\text { F:Experience } \\
\text { products, } \\
\text { no publicity, good } \\
\text { word of mouth }\end{array}$ & $\begin{array}{l}\text { ace } \\
\text { licity, no } \\
\text { mouth }\end{array}$ & $\begin{array}{l}\text { nce } \\
\text { s, } \\
\text { icity, good } \\
\text { mouth }\end{array}$ \\
\hline $\begin{array}{l}\text { C:Search } \\
\text { products, } \\
\text { with publicity, } \\
\text { no word of } \\
\text { mouth }\end{array}$ & $\begin{array}{l}\text { D:Search } \\
\text { products, } \\
\text { with publicity, } \\
\text { good word of } \\
\text { mouth }\end{array}$ & $\begin{array}{l}\text { ience } \\
\text { iblicity, no } \\
\text { mouth }\end{array}$ & $\begin{array}{l}\text { ence } \\
\text { licity, good } \\
\text { nouth }\end{array}$ & $\begin{array}{l}\text { ence } \\
\text { blicity, no } \\
\text { mouth }\end{array}$ & $\begin{array}{l}\text { L:Credence } \\
\text { products, with } \\
\text { publicity, } \\
\text { good word of } \\
\text { mouth }\end{array}$ \\
\hline
\end{tabular}

By comparing team A and team B, team A and team C, team E and team F, team E and team G, team I and team J, team I and team $\mathrm{K}$, we can see the differences of the possibility of shopping online, then we can test hypothesis 5.

By comparing the difference of the possibility of shopping online or offline in team A and team B, team A and team C, we can test hypothesis $5 \mathrm{a}$.

By comparing the difference of the possibility of shopping online or offline in team $\mathrm{E}$ and team $\mathrm{F}$, team $\mathrm{E}$ and team $\mathrm{G}$, we can test hypothesis $5 \mathrm{~b}$.

By comparing the difference of the possibility of shopping online or offline in team I and team J, team I and team $\mathrm{K}$, we can test hypothesis $5 \mathrm{c}$.

\subsection{Experiment 5}

Experiment 5 is a $3 \times 2$ design, to test hypothesis 6 . We chose 120 volunteers, who were divided into 6 teams, each with 20 volunteers. One third of each 60 volunteers would buy search products, one third would buy experience products, and the last one third would choose credence products.

Before they made the online shopping decisions, we would let them experience in the offline experience shop firstly. Half of them would enjoy high quality service, while the other half would experience normal service. The result of the 6 teams is shown below:

Table 5. Experiment 5 design

\begin{tabular}{ll}
\hline A:Search products, high quality service & B:Search products, normal service \\
\hline C:Experience products, high quality service & D:Experience products, normal service \\
E:Credence products, high quality service & F:Credence products, normal service \\
\hline
\end{tabular}

By comparing team A and team B, team C and team D, team E and team F, we can see the differences of the possibility of shopping online, then we can test hypothesis 6 .

By comparing the difference of the possibility of shopping online or offline in team A and team B, we can test hypothesis $6 a$.

By comparing the difference of the possibility of shopping online or offline in team C and team D, we can test hypothesis $6 \mathrm{~b}$.

By comparing the difference of the possibility of shopping online or offline in team $\mathrm{E}$ and team $\mathrm{F}$, we can test hypothesis 6c. 


\section{Data analyses and Results}

We test all the experiments to check the hypotheses.

\subsection{Test 1}

As we have 120 volunteers divided into 6 teams, each with 20 volunteers. The statistic result is shown below:

Table 6. The result of Test 1

\begin{tabular}{cccc}
\hline & Type & $\begin{array}{c}\text { Online shopping } \\
\text { volunteers }\end{array}$ & $\begin{array}{c}\text { Proportion of } \\
\text { purchasing }\end{array}$ \\
\hline A & Search products, direct shopping & 16 & $80 \%$ \\
B & Search products, reading complicated introduction before & 10 & $50 \%$ \\
Shopping & & $60 \%$ \\
C & Experience products, direct shopping & 12 & $50 \%$ \\
E & Experience products, reading complicated introduction before & 10 & $35 \%$ \\
F & Credenping & 7 & $30 \%$
\end{tabular}

We can see that the proportion of purchasing of team A is higher than team B, the proportion of purchasing of team $\mathrm{C}$ is higher than team $\mathrm{D}$, and team $\mathrm{E}$ is higher than team $\mathrm{F}$.

H1a: Firstly let's do the t-test regression for the comparison of team A and team B, as follows:

Paired t test

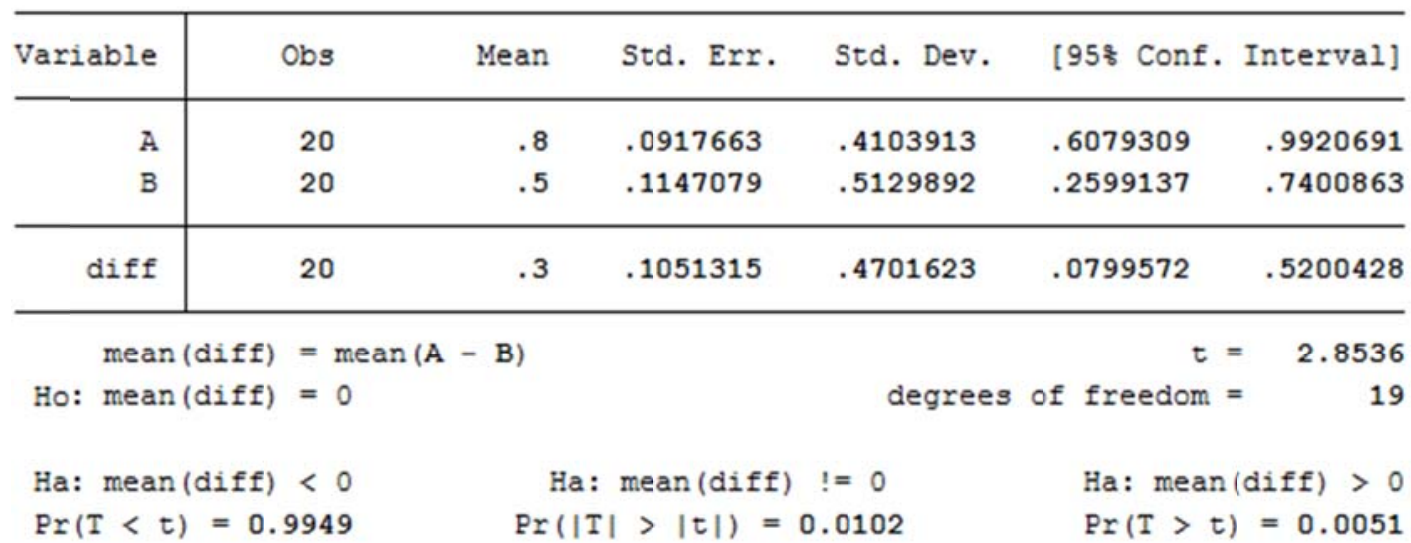

We can see that team A is significantly bigger than team B. So hypothesis 1a is correct, that is for search products, the simpler the online shopping process is, the possibility of the customers to use online channel will be much higher.

H1b: Second, let's do the t-test regression for the comparison of team C and team D, as follows:

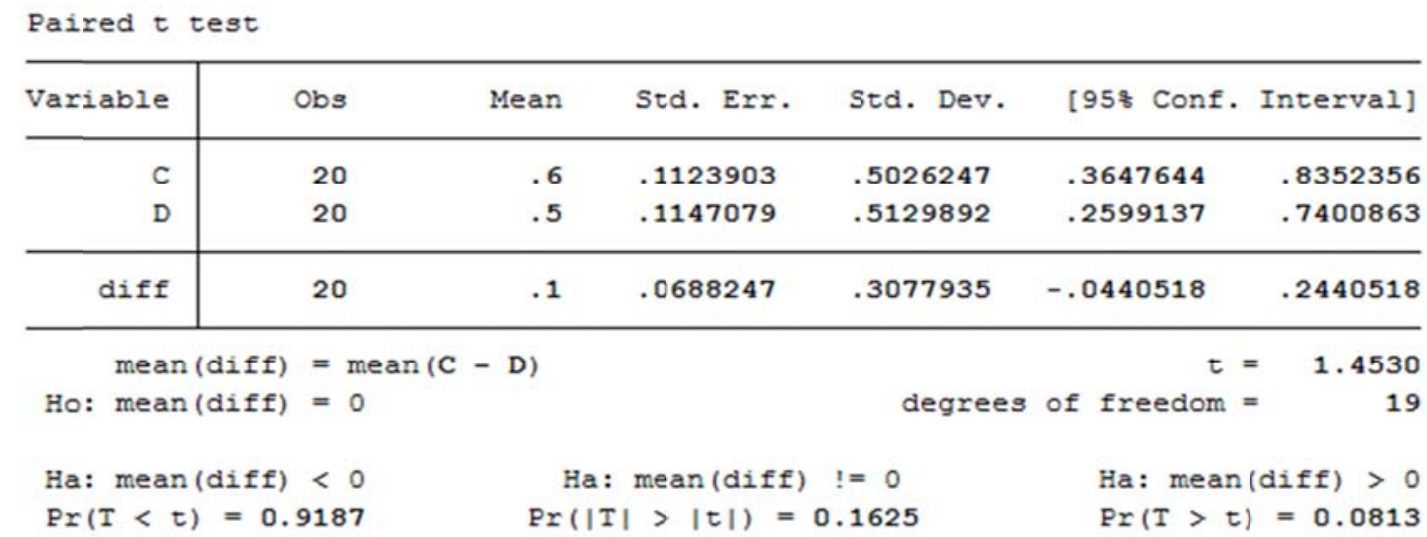

We can see that the p-values of both sides are larger than 0.05 , so team $C$ and team $D$ do not have significant difference. As a result, hypothesis $1 \mathrm{~b}$ is correct, that is for experience products, the simpler the online shopping 
process is, the possibility of the customers to use online channel will not increase significantly.

H1c: Third, let's do the t-test regression for the comparison of team E and team F, as follows:

\section{paired t test}

\begin{tabular}{|c|c|c|c|c|c|c|}
\hline variable & obs & Mean & Std. Err. & std. Dev. & [95\% conf. & Interval] \\
\hline$E$ & 20 & .3 & & & & \\
\hline diff & 20 & .05 & .1697 & .7591547 & -.30 & .405 \\
\hline \multicolumn{3}{|c|}{$\begin{array}{l}\operatorname{mean}(\text { diff })=\operatorname{mean}(\mathbf{E}-\mathbf{F} \\
\text { mean }(\text { diff })=0\end{array}$} & & degr & of freedom & $\begin{array}{r}0.2945 \\
19\end{array}$ \\
\hline \multicolumn{2}{|c|}{$\begin{array}{l}\text { Ha: mean (diff) }<0 \\
\operatorname{Pr}(T<t)=0.6142\end{array}$} & \multicolumn{3}{|c|}{$\begin{array}{c}\text { Ha: mean(diff) } !=0 \\
\operatorname{Pr}(|T|>|t|)=0.7715\end{array}$} & \multicolumn{2}{|c|}{$\begin{array}{l}\text { Ha: } \operatorname{mean}(\text { diff })>0 \\
\operatorname{Pr}(T>t)=0.3858\end{array}$} \\
\hline
\end{tabular}

We can see that the p-values of both sides are larger than 0.05 , so team $\mathrm{E}$ and team $\mathrm{F}$ do not have significant difference. As a result, hypothesis $1 \mathrm{c}$ is correct, that is for credence products, the simpler the online shopping process is, the possibility of the customers to use online channel will not increase significantly.

Summarizing all the 3 regressions, we can conclude that hypothesis 1 is supported, that is the simpler the online shopping process is, the more possible the customers will use online channel. However, only in the decision of search products purchasing, will the simplicity of online shopping process influence the consumers significantly.

\subsection{Test 2}

As we have 120 volunteers divided into 6 teams, each with 20 volunteers. The statistic result is shown below:

Table 7. The result of Test 2

\begin{tabular}{cccc}
\hline & Type & Online shopping volunteers & Proportion of purchasing \\
\hline A & Search products, nearby offline shop & 10 & $50 \%$ \\
B & Search products, long distance offline shop & 18 & $90 \%$ \\
C & Experience products, nearby offline shop & 10 & $50 \%$ \\
D & Experience products, long distance offline shop & 12 & $60 \%$ \\
E & Credence products, nearby offline shop & 7 & $35 \%$ \\
F & Credence products, long distance offline shop & 8 & $40 \%$ \\
\hline
\end{tabular}

We can see that the proportion of purchasing of team A is lower than team B, the proportion of purchasing of team $C$ is lower than team $D$, and team $E$ is not obviously different from team $F$.

H2a: Firstly let's do the t-test regression for the comparison of team A and team B, as follows:

Paired t test

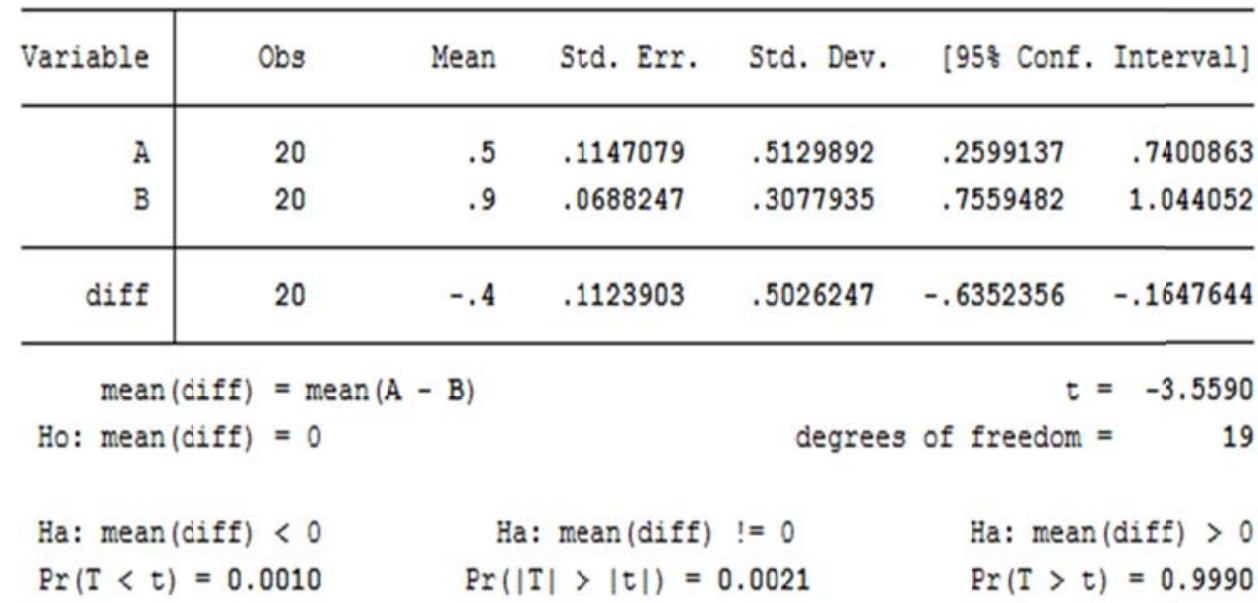


We can see that team A is significantly smaller than team B. So hypothesis 2a is correct, that is for search products, the longer the distance of the offline shop is, the possibility of the customers to use online channel will be much higher.

H2b: Second, let's do the t-test regression for the comparison of team C and team D, as follows:

\begin{tabular}{|c|c|c|c|c|c|c|}
\hline Variable & Obs & Mean & Std. Err. & Std. Dev. & [95\% Conf. & Interval] \\
\hline C & 20 & .5 & .1147079 & .5129892 & .2599137 & .7400863 \\
\hline D & 20 & .6 & .1123903 & .5026247 & .3647644 & .8352356 \\
\hline diff & 20 & -.1 & .1762176 & .7880689 & -.4688276 & .2688276 \\
\hline \multicolumn{2}{|c|}{$\operatorname{mean}($ diff $)=$} & - D) & & & $t=$ & $=-0.5675$ \\
\hline \multicolumn{2}{|c|}{ Ho: $\operatorname{mean}($ diff $)=$} & & & degrees & of freedom $=$ & 19 \\
\hline \multicolumn{2}{|c|}{ Ha: mean (diff) $<0$} & \multicolumn{2}{|c|}{ Ha: mean (diff) } & $!=0$ & \multicolumn{2}{|c|}{ Ha: mean (diff) $>0$} \\
\hline \multicolumn{2}{|c|}{$\operatorname{Pr}(I<t)=0.288$} & \multicolumn{3}{|c|}{$\operatorname{Pr}(|\mathrm{T}|>|t|)=0.5770$} & $\operatorname{Pr}(T>t)$ & $=0.7115$ \\
\hline
\end{tabular}

We can see that the p-values of both sides are larger than 0.05 , so team C and team D do not have significant difference. As a result, hypothesis $2 \mathrm{~b}$ is correct, that is for experience products, the longer the distance of the offline shop is, the possibility of the customers to use online channel will not increase significantly.

H2c: Third, let's do the t-test regression for the comparison of team $\mathrm{E}$ and team F, as follows:

Paired test

\begin{tabular}{|c|c|c|c|c|c|c|}
\hline variable & obs & Mean & Std. Err. & std. Dev. & [95\% conf. & Interval] \\
\hline$E$ & 20 & .35 & .1094243 & .4893605 & .1209722 & .5790278 \\
\hline $\mathrm{F}$ & 20 & .4 & .1123903 & .5026247 & .1647644 & .6352356 \\
\hline diff & 20 & -.05 & .1697521 & .7591547 & -.4052953 & .3052953 \\
\hline \multicolumn{4}{|c|}{$\begin{array}{l}\operatorname{mean}(\text { diff })=\operatorname{mean}(\mathbf{E}-\mathbf{F}) \\
\operatorname{mean}(\text { diff })=0\end{array}$} & degrees & of freedom & $\begin{array}{r}-0.2945 \\
19\end{array}$ \\
\hline \multicolumn{2}{|c|}{$\begin{array}{l}\text { Ha: mean(diff) }<0 \\
\operatorname{Pr}(T<t)=0.3858\end{array}$} & \multicolumn{3}{|c|}{$\begin{array}{c}\text { Ha: mean(diff) } !=0 \\
\operatorname{Pr}(|T|>|t|)=0.7715\end{array}$} & \multicolumn{2}{|c|}{$\begin{array}{l}\text { Ha: mean(diff) }>0 \\
\operatorname{Pr}(T>t)=0.6142\end{array}$} \\
\hline
\end{tabular}

We can see that the p-values of both sides are larger than 0.05 , so team $\mathrm{E}$ and team $\mathrm{F}$ do not have significant difference, and the proportion of purchasing of the 2 teams is so close. As a result, hypothesis $2 \mathrm{c}$ is correct, that is for credence products, the longer the distance of the offline shop is, the possibility of the customers to use online channel will almost stay the same.

Summarizing all the 3 regressions, we can conclude that hypothesis 2 is supported, that is the longer the distance of the offline shop is, the more likely the customers will use online channel. However, only in the decision of search products purchasing will the distance of offline shop influence the consumers significantly.

\subsection{Test 3}

As we have 120 volunteers divided into 12 teams, each with 10 volunteers. The statistic result is shown below: 
Table 8 . The result of Test 3

\begin{tabular}{|c|c|c|c|}
\hline & Type & $\begin{array}{c}\text { Online shopping } \\
\text { volunteers }\end{array}$ & $\begin{array}{c}\text { Proportion of } \\
\text { purchasing }\end{array}$ \\
\hline A & Social active, search products, shopping alone & 5 & $50 \%$ \\
\hline B & Social active, experience products, shopping alone & 6 & $60 \%$ \\
\hline $\mathrm{C}$ & Social active, credence products, shopping alone & 5 & $50 \%$ \\
\hline $\mathrm{D}$ & Social active, search products, shopping with friends or relatives & 5 & $50 \%$ \\
\hline $\mathrm{E}$ & $\begin{array}{c}\text { Social active, experience products, shopping with friends or } \\
\text { relatives }\end{array}$ & 2 & $20 \%$ \\
\hline $\mathrm{F}$ & $\begin{array}{l}\text { Social active, credence products, shopping with friends or } \\
\text { relatives }\end{array}$ & 1 & $10 \%$ \\
\hline G & Social phobia, search products, shopping alone & 8 & $80 \%$ \\
\hline $\mathrm{H}$ & Social phobia, experience products, shopping alone & 8 & $80 \%$ \\
\hline I & Social phobia, credence products, shopping alone & 7 & $70 \%$ \\
\hline $\mathrm{J}$ & Social phobia, search products, shopping with friends or relatives & 4 & $40 \%$ \\
\hline $\mathrm{K}$ & $\begin{array}{l}\text { Social phobia, experience products, shopping with friends or } \\
\text { relatives }\end{array}$ & 3 & $30 \%$ \\
\hline $\mathrm{L}$ & $\begin{array}{l}\text { Social phobia, credence products, shopping with friends or } \\
\text { relatives }\end{array}$ & 2 & $20 \%$ \\
\hline
\end{tabular}

H3a: Firstly let's do the t-test regression for the comparison of team A and team D, as follows:

paired t test

\begin{tabular}{|c|c|c|c|c|c|c|}
\hline variable & obs & Mean & Std. Err. & std. Dev. & {$[95 \%$ conf. } & Interval] \\
\hline $\begin{array}{l}\text { A } \\
\text { D }\end{array}$ & $\begin{array}{l}10 \\
10\end{array}$ & $\begin{array}{l}.5 \\
.5\end{array}$ & $\begin{array}{l}.1666667 \\
.1666667\end{array}$ & $\begin{array}{l}.5270463 \\
.5270463\end{array}$ & $\begin{array}{l}.1229738 \\
.1229738\end{array}$ & $\begin{array}{l}.8770262 \\
.8770262\end{array}$ \\
\hline diff & 10 & 0 & 1490712 & .4714045 & -.3372225 & .3372225 \\
\hline \multicolumn{3}{|c|}{$\begin{array}{l}\operatorname{mean}(\operatorname{diff})=\operatorname{mean}(\mathbf{A}-\mathbf{D}) \\
\operatorname{mean}(\operatorname{diff})=0\end{array}$} & \multicolumn{3}{|c|}{ degrees of freedom $=$} & 0.0000 \\
\hline $\begin{array}{l}\text { на: mear } \\
\mathrm{Pr}(\mathrm{T}<\mathrm{t}\end{array}$ & $\begin{array}{l}<0 \\
5000\end{array}$ & & $\begin{array}{l}\operatorname{mean}(\text { diff } \\
>|t|)=\end{array}$ & $\begin{array}{l}=0 \\
0000\end{array}$ & $\begin{array}{l}\text { Ha: mean } \\
\operatorname{Pr}(T>t\end{array}$ & $\begin{array}{l}\text { (diff) }>0 \\
=0.5000\end{array}$ \\
\hline
\end{tabular}

We can see that the data of team A and team D are almost the same, so hypothesis 3a is correct, that is for search products, when shopping with friends or relatives, the possibility of social active customers to use online channel will not change a lot.

H3b: Second, let's do the t-test regression for the comparison of team B and team E, as follows:

paired $t$ test

\begin{tabular}{|c|c|c|c|c|c|c|}
\hline variable & obs & Mean & Std. Err. & Std. Dev. & [95\% Conf. & Interval] \\
\hline$B$ & 10 & .6 & .1632993 & .5163978 & .2305913 & 9694087 \\
\hline$E$ & 10 & .2 & .1333333 & .421637 & -.101621 & .501621 \\
\hline diff & 10 & .4 & .1632993 & .5163978 & .0305913 & .7694087 \\
\hline \multicolumn{4}{|c|}{$\begin{array}{l}\operatorname{mean}(\operatorname{diff})=\operatorname{mean}(\mathbf{B}-\mathbf{E}) \\
\operatorname{mean}(\operatorname{diff})=0\end{array}$} & \multicolumn{2}{|c|}{$\begin{aligned} t & = \\
\text { degrees of freedom } & =\end{aligned}$} & 2.4495 \\
\hline \multicolumn{2}{|c|}{$\begin{array}{l}\text { Ha: mean (diff) }<0 \\
\operatorname{Pr}(T<t)=0.9816\end{array}$} & \multicolumn{3}{|c|}{$\begin{array}{c}\text { Ha: mean(diff) } !=0 \\
\operatorname{Pr}(|T|>|t|)=0.0368\end{array}$} & \multicolumn{2}{|c|}{$\begin{array}{l}\text { Ha: mean (diff) }>0 \\
\operatorname{Pr}(T>t)=0.0184\end{array}$} \\
\hline
\end{tabular}

We can see that the data of team B is significantly bigger than team E, so hypothesis 3b is correct, that is for experience products, when shopping with friends or relatives, the possibility of social active customers to use online channel will be lower. 
H3c: Let's do the t-test regression for the comparison of team $\mathrm{C}$ and team $\mathrm{F}$, as follows:

Paired $t$ test

\begin{tabular}{|c|c|c|c|c|c|c|}
\hline variable & obs & Mean & std. Err. & std. Dev. & [95\% conf. & Interva1] \\
\hline C & 10 & .5 & .1666667 & .5270 & $\begin{array}{r}.1229738 \\
-1262157\end{array}$ & 262 \\
\hline & & & & & & \\
\hline diff & 10 & .4 & .2211083 & .6992059 & -.1001818 & . 9001818 \\
\hline \multicolumn{3}{|c|}{$\begin{array}{l}\operatorname{mean}(\text { diff })=\operatorname{mean}(\mathbf{C}-\mathbf{F}) \\
\operatorname{mean}(\text { diff })=0\end{array}$} & & degree & of freedom & 1.8091 \\
\hline \multicolumn{2}{|c|}{$\begin{array}{l}\text { Ha: } \operatorname{mean}(\text { diff })<0 \\
\operatorname{Pr}(T<t)=0.9481\end{array}$} & \multicolumn{3}{|c|}{$\begin{array}{c}\text { Ha: mean(diff) } !=0 \\
\operatorname{Pr}(|T|>|t|)=0.1039\end{array}$} & \multicolumn{2}{|c|}{$\begin{array}{l}\text { Ha: } \operatorname{mean}(\text { diff })>0 \\
\operatorname{Pr}(T>t)=0.0519\end{array}$} \\
\hline
\end{tabular}

We can see that the data of team $\mathrm{C}$ is significantly bigger than team $\mathrm{F}$, and the proportion of purchasing of team $\mathrm{F}$ is smaller than team E, so hypothesis 3c is correct, that is for credence products, when shopping with friends or relatives, the possibility of social active customers to use online channel will be even lower than experience products consumers.

Summarizing all the 3 regressions above, we can conclude that hypothesis 3 is supported, that is social active consumers prefer offline channel. What's more, this effect will be especially obvious within the decisions of experience products and credence products.

H4a: Let's do the t-test regression for the comparison of team $G$ and team J, as follows:

\begin{tabular}{|c|c|c|c|c|c|c|}
\hline variable & obs & Mean & std. Err. & std. Dev. & [95\% conf. & Interval] \\
\hline G & $\begin{array}{l}10 \\
10\end{array}$ & $\begin{array}{l}.8 \\
.4\end{array}$ & $\begin{array}{l}.1333333 \\
.1632993\end{array}$ & $\begin{array}{r}.421637 \\
.5163978\end{array}$ & $\begin{array}{r}.498379 \\
.0305913\end{array}$ & $\begin{array}{l}1.101621 \\
.7694087\end{array}$ \\
\hline diff & 10 & .4 & .2211083 & .6992059 & -.1001818 & .9001818 \\
\hline \multicolumn{3}{|c|}{$\begin{aligned} \operatorname{mean}(\text { diff }) & =\operatorname{mean}(\mathbf{G}-\mathbf{J} \\
\operatorname{mean}(\text { diff }) & =0\end{aligned}$} & \multicolumn{4}{|c|}{$\begin{aligned} t & = & \mathbf{1 . 8 0 9 1} \\
\text { degrees of freedom } & = & 9\end{aligned}$} \\
\hline \multicolumn{2}{|c|}{$\begin{array}{l}\text { Ha: } \operatorname{mean}(\text { diff })<0 \\
\operatorname{Pr}(T<t)=0.9481\end{array}$} & \multicolumn{3}{|c|}{$\begin{array}{c}\text { Ha: mean(diff) } !=0 \\
\operatorname{Pr}(|T|>|t|)=0.1039\end{array}$} & \multicolumn{2}{|c|}{$\begin{array}{l}\text { Ha: } \operatorname{mean}(\text { diff })>0 \\
\operatorname{Pr}(T>t)=0.0519\end{array}$} \\
\hline
\end{tabular}

We can see that the data of team $G$ is significantly bigger than team $J$ so hypothesis 4 a is correct, that is for search products, when shopping with friends or relatives, the possibility of social phobia customers to use online channel will be lower.

H4b: Let's do the t-test regression for the comparison of team $\mathrm{H}$ and team $\mathrm{K}$, as follows:

paired t test

\begin{tabular}{|c|c|c|c|c|c|c|}
\hline Variable & obs & Mean & Std. Err. & Std. Dev. & [95\% conf. & Interval] \\
\hline $\begin{array}{l}\mathrm{H} \\
\mathrm{K}\end{array}$ & $\begin{array}{l}10 \\
10\end{array}$ & $\begin{array}{l}.8 \\
.3\end{array}$ & $\begin{array}{l}.1333333 \\
.1527525\end{array}$ & $\begin{array}{r}.421637 \\
.4830459\end{array}$ & $\begin{array}{r}.498379 \\
-.0455502\end{array}$ & $\begin{array}{l}1.101621 \\
.6455502\end{array}$ \\
\hline diff & 10 & .5 & .2236068 & .7071068 & -.0058337 & 1.005834 \\
\hline \multicolumn{4}{|c|}{$\begin{aligned} \operatorname{mean}(\operatorname{diff}) & =\operatorname{mean}(\mathbf{H}-\mathbf{K}) \\
\operatorname{mean}(\operatorname{diff}) & =0\end{aligned}$} & degre & of freedom & $\begin{array}{r}2.2361 \\
9\end{array}$ \\
\hline \multicolumn{2}{|c|}{$\begin{array}{l}\text { Ha: mean(diff) } \\
\operatorname{Pr}(T<t)=0.973\end{array}$} & \multicolumn{3}{|c|}{$\begin{array}{c}\text { Ha: mean(diff) } !=0 \\
\operatorname{Pr}(|\mathrm{T}|>|t|)=0.0522\end{array}$} & \multicolumn{2}{|c|}{$\begin{array}{l}\text { Ha: } \operatorname{mean}(\text { diff })>0 \\
\operatorname{Pr}(T>t)=0.0261\end{array}$} \\
\hline
\end{tabular}

We can see that the data of team $\mathrm{H}$ is significantly bigger than team $\mathrm{K}$ and the proportion of purchasing of team 
$\mathrm{K}$ is smaller than team $\mathrm{J}$, so hypothesis $4 \mathrm{~b}$ is correct, that is for experience products, when shopping with friends or relatives, the possibility of social phobia customers to use online channel will be even lower than search products consumers.

H4c: Let's do the t-test regression for the comparison of team I and team L, as follows:

paired t test

\begin{tabular}{|c|c|c|c|c|c|c|}
\hline variable & obs & Mean & Std. Err. & std. Dev. & [95\% conf. & Interval] \\
\hline I & 10 & .7 & .15275 & .4830459 & .35 & 1. 04555 \\
\hline L & 10 & .2 & .1333333 & .421637 & -.101621 & .501621 \\
\hline diff & 10 & .5 & .2236068 & .7071068 & -.0058337 & 1.005834 \\
\hline \multicolumn{4}{|c|}{$\begin{aligned} \operatorname{mean}(\operatorname{diff}) & =\operatorname{mean}(\mathbf{I}-\mathbf{L}) \\
\text { Ho: } \operatorname{mean}(\operatorname{diff}) & =0\end{aligned}$} & \multicolumn{3}{|c|}{$\begin{aligned} t & = & 2.2361 \\
\text { degrees of freedom } & = & 9\end{aligned}$} \\
\hline \multicolumn{2}{|c|}{$\begin{array}{l}\text { Ha: mean }(\text { diff })<0 \\
\operatorname{Pr}(T<t)=0.9739\end{array}$} & \multicolumn{3}{|c|}{$\begin{array}{c}\text { Ha: mean(diff) } !=0 \\
\operatorname{Pr}(|T|>|t|)=0.0522\end{array}$} & \multicolumn{2}{|c|}{$\begin{array}{l}\text { Ha: mean (diff) }>0 \\
\operatorname{Pr}(T>t)=0.0261\end{array}$} \\
\hline
\end{tabular}

We can see that the data of team I is significantly bigger than team $\mathrm{L}$ and the proportion of purchasing of team $\mathrm{L}$ is smaller than team $\mathrm{K}$, so hypothesis $4 \mathrm{c}$ is correct, that is for credence products, when shopping with friends or relatives, the possibility of social phobia customers to use online channel will be even lower than experience products consumers.

Summarizing all the 3 regressions above, we can conclude that hypothesis 4 is supported, that is social phobia consumers prefer online channel.

\subsection{Test 4}

As we have 120 volunteers divided into 12 teams, each with 10 volunteers. The statistic result is shown below:

Table 9. The result of Test 4

\begin{tabular}{cccc}
\hline & Type & Online shopping volunteers & Proportion of purchasing \\
\cline { 2 - 4 } A & Search products, no publicity, no word of mouth & 4 & $40 \%$ \\
B & Search products no publicity, good word of mouth & 6 & $60 \%$ \\
C & Search products, with publicity, no word of mouth & 5 & $50 \%$ \\
D & Search products, with publicity, good word of mouth & 6 & $60 \%$ \\
E & Experience products, no publicity, no word of mouth & 4 & $40 \%$ \\
F & Experience products,, no publicity, good word of mouth & 8 & $80 \%$ \\
G & Experience products, with publicity, no word of mouth & 8 & $80 \%$ \\
H & Experience products, with publicity, good word of mouth & 9 & $90 \%$ \\
I & Credence products, no publicity, no word of mouth & 2 & $20 \%$ \\
J & Credence products, no publicity, good word of mouth & 6 & $60 \%$ \\
K & Credence products, with publicity, no word of mouth & 6 & $60 \%$ \\
L & Credence products, with publicity, good word of mouth & 7 & $70 \%$ \\
\hline
\end{tabular}

H5a: Firstly let's do the t-test regression for the comparison of team A and team B, as follows:

paired $t$ test

\begin{tabular}{|c|c|c|c|c|c|c|}
\hline variable & obs & Mean & std. Err. & Std. Dev. & [95\% conf. & Interval] \\
\hline$A$ & 10 & .4 & .1632993 & .51639 & & .76 \\
\hline B & & & & & & \\
\hline diff & 10 & -.2 & .2 & .6324555 & -.6524314 & .2524314 \\
\hline \multicolumn{4}{|c|}{$\begin{aligned} \operatorname{mean}(\operatorname{diff}) & =\operatorname{mean}(\mathbf{A}-\mathbf{B}) \\
\text { mean }(\operatorname{diff}) & =0\end{aligned}$} & \multicolumn{3}{|c|}{$\begin{aligned} t & = & -\mathbf{1 . 0 0 0 0} \\
\text { degrees of freedom } & = & 9\end{aligned}$} \\
\hline \multicolumn{2}{|c|}{$\begin{array}{l}\text { Ha: mean (diff) }< \\
\operatorname{Pr}(T<t)=0.171\end{array}$} & & $\begin{array}{l}\operatorname{mean}(\operatorname{dif} \\
>|\mathrm{t}|)\end{array}$ & $\begin{array}{l}=0 \\
3434\end{array}$ & \multicolumn{2}{|c|}{$\begin{array}{l}\text { Ha: } \operatorname{mean}(\text { diff })>0 \\
\operatorname{Pr}(T>t)=0.8283\end{array}$} \\
\hline
\end{tabular}


Then let's do the t-test regression for the comparison of team A and team C, as follows:

paired $t$ test

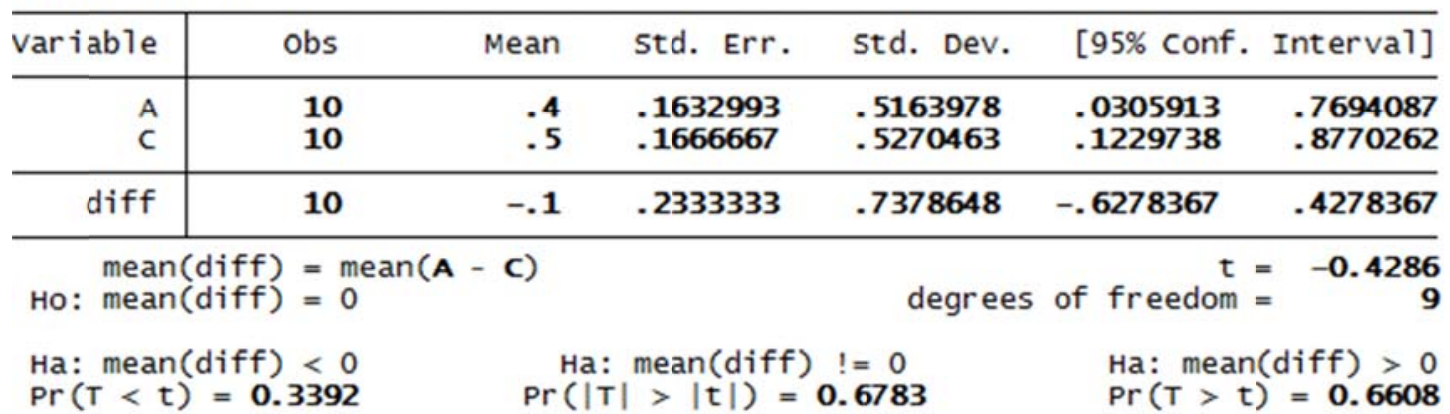

For the comparison of team $\mathrm{A}$ and team $\mathrm{B}$, we can see that the p-values of both sides are larger than 0.05 , so team A and team B do not have significant difference. For the comparison of team A and team C, we can see that the p-values of both sides are larger than 0.05 , so team $A$ and team $C$ do not have significant difference, either. So hypothesis 5a is correct, that is for search products, good word of mouth and publicity from neutral media and websites will not make a big improvement in long-term sales of online channel.

H5b: Let's do the t-test regression for the comparison of team $\mathrm{E}$ and team $\mathrm{F}$, as follows:

Paired t test

\begin{tabular}{|c|c|c|c|c|c|c|}
\hline variable & obs & Mean & Std. Err. & std. Dev. & [95\% conf. & Interval] \\
\hline $\mathrm{E}$ & 10 & .4 & 16329 & 5163978 & .0305913. & .769 \\
\hline $\mathrm{F}$ & 10 & .8 & .133333 & .421637 & .49 & 1.101621 \\
\hline diff & 10 & -.4 & .2211083 & .6992059 & -.9001818 & .1001818 \\
\hline \multicolumn{3}{|c|}{$\begin{aligned} \operatorname{mean}(\operatorname{diff}) & =\operatorname{mean}(\mathbf{E}-\mathbf{F}) \\
\text { Ho: } \operatorname{mean}(\operatorname{diff}) & =0\end{aligned}$} & \multicolumn{4}{|c|}{$\begin{array}{rlr}t & =-\mathbf{1 . 8 0 9 1} \\
\text { degrees of freedom } & = & 9\end{array}$} \\
\hline \multicolumn{2}{|c|}{$\begin{array}{l}\text { Ha: mean(diff) }<0 \\
\operatorname{Pr}(T<t)=0.0519\end{array}$} & \multicolumn{3}{|c|}{$\begin{array}{l}\text { Ha: mean(diff) } !=0 \\
\operatorname{Pr}(|T|>|t|)=0.1039\end{array}$} & \multicolumn{2}{|c|}{$\begin{array}{l}\text { Ha: mean(diff) }>0 \\
\operatorname{Pr}(T>t)=0.9481\end{array}$} \\
\hline
\end{tabular}

Then let's do the t-test regression for the comparison of team E and team G, as follows:

\section{paired t test}

\begin{tabular}{|c|c|c|c|c|c|c|}
\hline variable & obs & Mean & Std. Err. & Std. Dev. & [95\% conf. & Interval] \\
\hline E & 10 & .4 & .1632993 & .5163978 & .0305913 & .7694087 \\
\hline$G$ & 10 & .8 & .1333333 & .421637 & .498379 & 1.101621 \\
\hline diff & 10 & -.4 & .1632993 & .5163978 & -.7694087 & -.0305913 \\
\hline \multicolumn{4}{|c|}{$\begin{aligned} \operatorname{mean}(\operatorname{diff}) & =\operatorname{mean}(\mathbf{E}-\mathbf{G}) \\
\text { Ho: } \operatorname{mean}(\operatorname{diff}) & =0\end{aligned}$} & \multicolumn{3}{|c|}{$\begin{aligned} t & = & -2.4495 \\
\text { degrees of freedom } & = & 9\end{aligned}$} \\
\hline \multicolumn{2}{|c|}{$\begin{array}{l}\text { Ha: mean (diff) }<0 \\
\operatorname{Pr}(T<t)=0.0184\end{array}$} & \multicolumn{3}{|c|}{$\begin{array}{l}\text { Ha: mean(diff) } !=0 \\
\operatorname{Pr}(|T|>|t|)=0.0368\end{array}$} & \multicolumn{2}{|c|}{$\begin{array}{l}\text { Ha: mean (diff) }>0 \\
\operatorname{Pr}(T>t)=0.9816\end{array}$} \\
\hline
\end{tabular}

For the comparison of team $\mathrm{E}$ and team $\mathrm{F}$, we can see that the data of team $\mathrm{E}$ is significantly smaller than team $\mathrm{F}$. For the comparison of team $E$ and team $G$, we can see that the data of team $E$ is significantly smaller than team G. So hypothesis $5 b$ is correct, that is for experience products, good word of mouth and publicity from neutral media and websites will make a big improvement in long-term sales of online channel. 
H5c: Let's do the t-test regression for the comparison of team I and team J as follows:

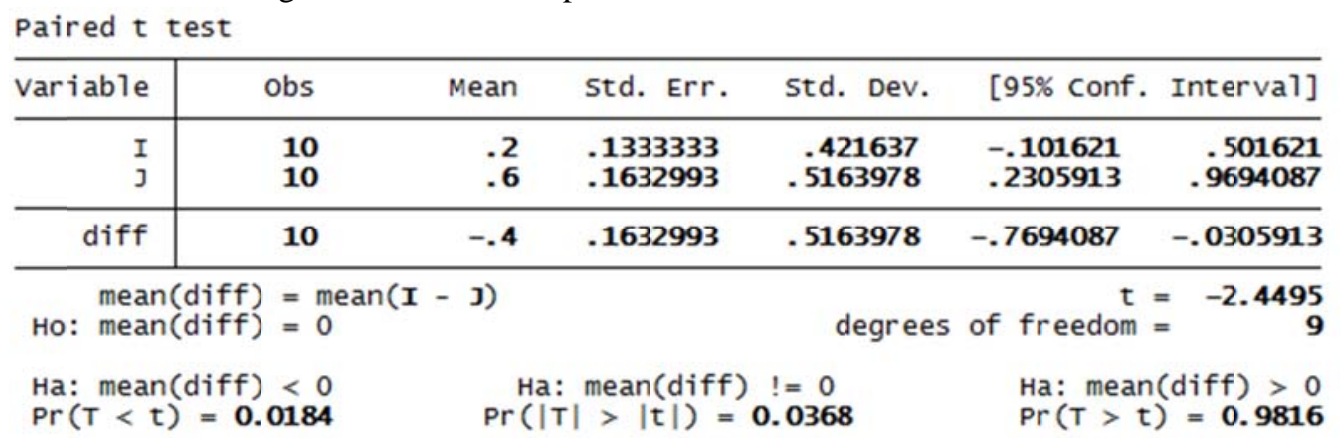

Then let's do the t-test regression for the comparison of team I and team K, as follows:

\begin{tabular}{|c|c|c|c|c|c|c|}
\hline variable & obs & Mean & Std. Err. & std. Dev. & [95\% conf. & Interval] \\
\hline$I$ & 10 & .2 & .1333333 & .421637 & -.101621 & . 501621 \\
\hline K & 10 & .6 & .1632993 & . 5163978 & .2305913 & .9694087 \\
\hline diff & 10 & -.4 & .2211083 & .6992059 & -.9001818 & .1001818 \\
\hline \multicolumn{2}{|c|}{$\begin{aligned} \operatorname{mean}(\text { diff }) & = \\
\text { Ho: } \operatorname{mean}(\text { diff }) & =\end{aligned}$} & $-\boldsymbol{K})$ & & degrees & of freedom & $\begin{array}{rr}= & -1.8091 \\
= & 9\end{array}$ \\
\hline \multicolumn{2}{|c|}{$\begin{array}{l}\text { Ha: } \operatorname{mean}(\text { diff })<0 \\
\operatorname{Pr}(T<t)=0.0519\end{array}$} & \multicolumn{3}{|c|}{$\begin{array}{c}\text { Ha: mean(diff) } !=0 \\
\operatorname{Pr}(|\mathrm{T}|>|t|)=\mathbf{0 . 1 0 3 9}\end{array}$} & \multicolumn{2}{|c|}{$\begin{array}{l}\text { Ha: mean (diff) }>0 \\
\operatorname{Pr}(T>t)=0.9481\end{array}$} \\
\hline
\end{tabular}

For the comparison of team I and team J, we can see that the data of team I is significantly smaller than team J, and the proportion of purchasing of team $\mathrm{J}$ is smaller than team F. For the comparison of team I and team $\mathrm{K}$, we can see that the data of team I is significantly smaller than team $\mathrm{K}$, and the proportion of purchasing of team $\mathrm{K}$ is smaller than team G. So hypothesis $5 c$ is correct, that is for credence products, good word of mouth and publicity from neutral media and websites will make a big improvement in long-term sales of online channel, but the improvement will be less than in experience products.

Summarizing all the 6 regressions above, we can conclude that hypothesis 5 is supported, that is good word of mouth and publicity from neutral media and websites will increase long-term sales of online channel.

\subsection{Test 5}

As we have 120 volunteers divided into 6 teams, each with 20 volunteers. The statistic result is shown below:

Table 10 . The result of Test 5

\begin{tabular}{cccc}
\hline & Type & Online shopping volunteers & Proportion of purchasing \\
\hline A & Search products, high quality service & 16 & $80 \%$ \\
B & Search products, normal service & 11 & $55 \%$ \\
C & Experience products, high quality service & 16 & $80 \%$ \\
D & Experience products, normal service & 8 & $40 \%$ \\
E & Credence products, high quality service & 6 & $30 \%$ \\
F & Credence products, normal service & 5 & $25 \%$ \\
\hline
\end{tabular}

H6a: Firstly let's do the t-test regression for the comparison of team A and team B, as follows:

\begin{tabular}{|c|c|c|c|c|c|c|}
\hline variable & obs & Mean & std. Err. & std. Dev. & [95\% conf. & Interva1] \\
\hline $\begin{array}{l}A \\
B\end{array}$ & $\begin{array}{l}20 \\
20\end{array}$ & .85 & $\begin{array}{l}.0917663 \\
.1141329\end{array}$ & $\begin{array}{l}.4103913 \\
.5104178\end{array}$ & $\begin{array}{l}.6079309 \\
.3111171\end{array}$ & $\begin{array}{l}.9920691 \\
.7888829\end{array}$ \\
\hline diff & 20 & .25 & .1428101 & .6386664 & -.0489051 & .5489051 \\
\hline \multicolumn{2}{|c|}{$\begin{array}{r}\operatorname{mean}(\text { diff })= \\
\text { Ho: } \operatorname{mean}(\text { diff })=\end{array}$} & B) & & degrees & $\begin{aligned} t & = \\
\text { of freedom } & =\end{aligned}$ & $\begin{array}{r}1.7506 \\
19\end{array}$ \\
\hline \multicolumn{2}{|c|}{$\begin{array}{l}\text { Ha: mean (diff) }<0 \\
\operatorname{Pr}(T<t)=0.9519\end{array}$} & $\operatorname{Pr}$ & $\begin{array}{l}\operatorname{mean}(\text { diff }) \\
|>| t \mid)=\end{array}$ & $\begin{array}{l}!=0 \\
0961\end{array}$ & \multicolumn{2}{|c|}{$\begin{array}{l}\text { Ha: } \operatorname{mean}(\text { diff })>0 \\
\operatorname{Pr}(T>t)=0.0481\end{array}$} \\
\hline
\end{tabular}


We can see that team A is significantly bigger than team B. So hypothesis 6a is correct, that is for search products, the higher the perceived offline service quality of customers is, the more likely that the customers will consume online.

H6b: Second, let's do the t-test regression for the comparison of team C and team D, as follows:

\begin{tabular}{|c|c|c|c|c|c|c|}
\hline variable & obs & Mean & std. Err. & std. Dev. & [95\% conf. & Interva1] \\
\hline $\begin{array}{l}C \\
D\end{array}$ & $\begin{array}{l}20 \\
20\end{array}$ & $\begin{array}{l}.8 \\
.4\end{array}$ & $\begin{array}{l}.0917663 \\
.1123903\end{array}$ & $\begin{array}{l}.4103913 \\
.5026247\end{array}$ & $\begin{array}{l}.6079309 \\
.1647644\end{array}$ & $\begin{array}{l}.9920691 \\
.6352356\end{array}$ \\
\hline diff & 20 & .4 & .1521772 & .680557 & .0814895 & .7185105 \\
\hline \multicolumn{3}{|c|}{$\begin{array}{l}\text { mean(diff) } \\
\text { mean(diff) }\end{array}$} & \multicolumn{3}{|c|}{$\begin{array}{r}t= \\
\text { degrees of freedom }=\end{array}$} & $\begin{array}{r}2.6285 \\
19\end{array}$ \\
\hline \multicolumn{2}{|c|}{$\begin{array}{l}\text { Ha: mean(diff) }<0 \\
\operatorname{Pr}(T<t)=0.9917\end{array}$} & $\operatorname{Pr}{ }^{H}$ & $\begin{array}{l}\operatorname{mean}(\text { diff } \\
|>| t \mid)=\end{array}$ & $\begin{array}{l}!=0 \\
.0165\end{array}$ & \multicolumn{2}{|c|}{$\begin{array}{l}\text { Ha: mean(diff) }>0 \\
\operatorname{Pr}(T>\tau)=0.0083\end{array}$} \\
\hline
\end{tabular}

We can see that team C is significantly bigger than team D, and the proportion of purchasing of team $\mathrm{D}$ is smaller than team B. So hypothesis $6 \mathrm{~b}$ is correct, that is for experience products, the higher the perceived offline service quality of customers is, the more likely that the customers will consume online, and the possibility will be even higher than search products.

H6c: Third, let's do the t-test regression for the comparison of team $\mathrm{E}$ and team $\mathrm{F}$, as follows:

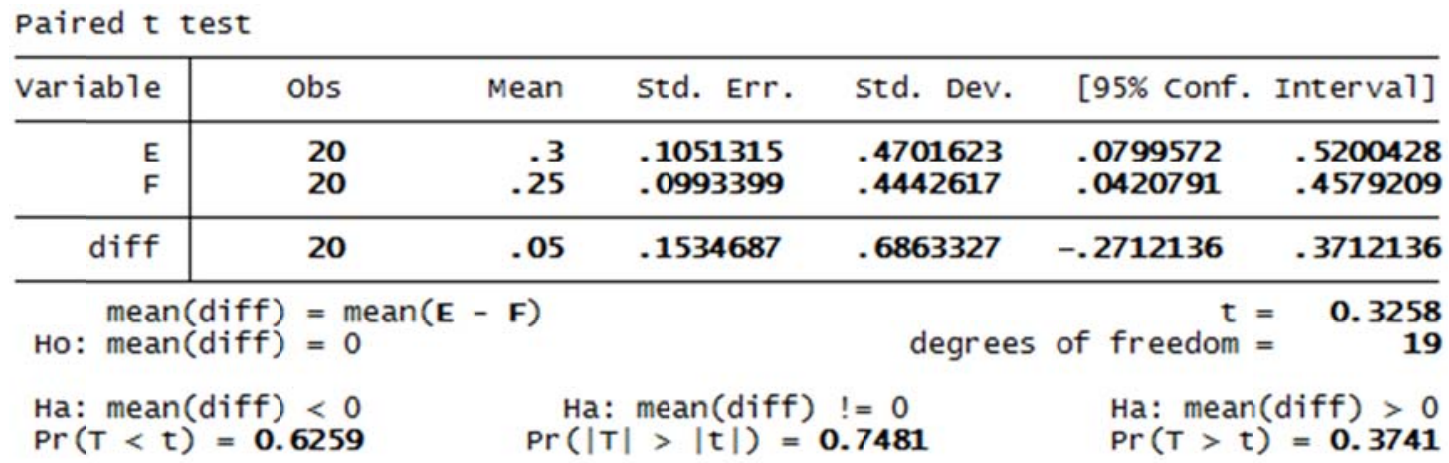

We can see that the p-values of both sides are larger than 0.05 , so team $\mathrm{E}$ and team $\mathrm{F}$ do not have significant difference. As a result, hypothesis $6 \mathrm{c}$ is correct, that is for credence products, the higher the perceived offline service quality of customers is, the possibility of customers' online consumption will not increase significantly.

Summarizing all the 3 regressions, we can conclude that hypothesis 6 is supported, that is the higher the perceived offline service quality of customers is, the more likely that the customers will consume online.

\section{Conclusion and Discussions}

The research focuses on customers' decision between online or offline channel about search products, experience products and credence products. We study this question by 6 hypotheses, discussing the influence of 5 factors, named website design, offline shop distance, customer group selection, media publicity and offline channel's help for online.

1. Website design: Generally speaking, the simpler the online shopping process is, the more possible the customers will use online channel. For search products, the simpler the online shopping process is, the possibility of the customers to use online channel will be much higher. For experience products, the simpler the online shopping process is, the possibility of the customers to use online channel will not increase significantly. For credence products, the simpler the online shopping process is, the possibility of the customers to use online channel will not increase significantly.

Originally, people will hate complicated online shopping process.(Raquel Chocarro and Mónica Cortinas, 2013) However, for experience products consumers, online introduction will be important for them to know the performance of products, so they will not feel so disgusted about complicated website process. For credence products consumers, online details are still not enough, so they will not care about the online process so much.

2. Offline shop distance: In a general way, the longer the distance of the offline shop is, the more likely the 
customers will use online channel. For search products, the longer the distance of the offline shop is, the possibility of the customers to use online channel will be much higher. For experience products, the longer the distance of the offline shop is, the possibility of the customers to use online channel will not increase significantly. For credence products, the longer the distance of the offline shop is, the possibility of the customers to use online channel will almost stay the same.

If all the other factors stay the same, customers will choose nearby offline shop.(Raquel Chocarro, Mónica Cortinas and María-Luisa Villanueva, 2013) However, for experience products consumers and credence products consumers, offline shop experience is a necessary step, because they cannot know the performance and quality without experiencing.

3. Customer group selection: On the whole, social active consumers prefer offline channel, while social phobia consumers prefer online channel. For search products, when shopping with friends or relatives, the possibility of social active customers to use online channel will not change a lot, while the possibility of social phobia customers to use online channel will be lower. For experience products, when shopping with friends or relatives, the possibility of social active customers to use online channel will be lower, while the possibility of social phobia customers to use online channel will be even lower than search products consumers. For credence products, when shopping with friends or relatives, the possibility of social active customers to use online channel will be even lower than experience products consumers, while the possibility of social phobia customers to use online channel will be even lower than experience products consumers.

Social active consumers naturally prefer offline channel, so shopping with friends or relatives will not make a difference. For experience products, social active consumers have necessary need for offline shop experience. For credence products, social active consumers will feel more happiness in offline shop than experience products, because the staffs' introduction can help them know the products better.

Social phobia consumers prefer online channel, but shopping with friends or relatives will reduce their fear of social communication, which can improve their willingness to offline shop. For experience products consumers, this effect will be more significant, because it's difficult for them to judge the performance of products if they don't go to the offline shop. While the effect will be even more obvious for credence products consumers, who have more need for products details.

4. Media publicity: For search products, good word of mouth and publicity from neutral media and websites will not make a big improvement in long-term sales of online channel. For experience products, good word of mouth and publicity from neutral media and websites will make a big improvement in long-term sales of online channel. For credence products, good word of mouth and publicity from neutral media and websites will make a big improvement in long-term sales of online channel, but the improvement will be less than in experience products.

Objectively, good word of mouth and publicity from neutral media and websites will increase long-term sales of online channel. (Koen Pauwels, Peter S.H. Leeflang, Marije L. Teerling and K.R. Eelko Huizingh, 2011) However, people can judge the quality and performance of search products easily, so the influence of word of mouth and publicity from neutral media and websites will not be very obvious for search products. For experience products and credence products consumers, making this judgment will be difficult. As a result, word of mouth and publicity from neutral media and websites will be more important. For credence products consumers, word of mouth and publicity from neutral media and websites are not enough, so the effect will be not as significant as experience products.

5. Offline channel's help for online: The higher the perceived offline service quality of customers is, the more likely that the customers will consume online. For search products, the higher the perceived offline service quality of customers is, the more likely that the customers will consume online. For experience products, the higher the perceived offline service quality of customers is, the more likely that the customers will consume online, and the possibility will be even higher than search products. For credence products, the higher the perceived offline service quality of customers is, the possibility of customers' online consumption will not increase significantly.

Generally speaking, if consumers can feel good perceived service quality in the offline experience shop, they online consumption will increase as well. (Shuiqing Yang, Yaobin Lu, Ling Zhao and Sumeet Gupta, 2011) While for the experience products consumers, offline experience will be very helpful for them to know the products performance, so this effect on online consumption is more significant. However, for credence products consumers, even if they feel good perceived service quality in the offline shop, they will not likely choose online channel, because it is far away from their natural preference. 
According to our findings, we can have some implications:

1. Website guide is important to let customers know the quality and performance of products well.

2. Experience products customers are the key emphases because they are easily transferred from offline channel to online channel if relevant requirements are met.

3. Word of mouth and publicity from neutral media and websites will be useful, especially for search products and experience products customers.

4. Online shops should pay more attention to social phobia consumers, because they will be more likely to shop online.

5. Offline experience shops should not be too far away from densely populated areas, and good offline experience will help online sales.

However, our study still has some shortage, which can be improved during future research. First, we don't pay enough attention to the interactive influence of different factors, which will be more interesting. Second, if we can have more diversified volunteers, the result will be more convincing. Third, we cannot find much theory support for credence products, which should be added to in the future. Fourth, we don't consider the difference brought by the brands, like private labels and national brands. (Marta Arce-Urriza, \& Javier Cebollada, 2012)

\section{References}

Darron, B., Ajay, K., \& George, L. (2011). Underpredicting Learning after Initial Experience with a Product. Journal of Consumer Research Inc., 37.

Dhruv, G., Ramkumar, J., Kirthi, K., Kannan, P. K., Brian, R. F., Reo, S., \& Stephen, T. (2010). Strategic Online and Offline Retail Pricing: A Review and Research Agenda. Journal of Interactive Marketing, 24, 138-154. http://dx.doi.org/10.1016/j.intmar.2010.02.007

Gee-Woo, B., Jumin, L., Huei, H. K., \& Jong, H. K. (2012). The progression of online trust in the multi-channel retailer context and the role of product uncertainty. Decision Support Systems, 53, 97-107. http://dx.doi.org/10.1016/j.dss.2011.12.007

Gila, E. F., \& Charles, S. T. (2005). Dynamic online and offline channel pricing for heterogeneous customers in virtual acceptance. International Game Theory Review, 7(2), 137-150. http://dx.doi.org/10.1142/S0219198905000454

Goksel, Y., \& Tevfik, A. (2015). Brand Extension Effects and Core Attributes of Experience Product Franchises: A Bayesian Approach. Journal of Product Innovation Management, 32(5), 731-746. http://dx.doi.org/10.1111/jpim.12164

Jeen-Su, L., Abdulrahman, A. A., \& John, H. H. (2015). Impact of satisfaction with e-retailers' touch points on purchase behavior: the moderating effect of search and experience product type. Marketing Letters, 26(1-1).

Koen, P., Peter, S. H. L., Marije, L. T., \& Huizingh, K. R. E. (2011). Does Online Information Drive Offline Revenues? Only for Specific Products and Consumer Segments. Journal of Retailing, 87, 1-17. http://dx.doi.org/10.1016/j.jretai.2010.10.001

Marta, A. U., \& Javier, C. (2012). Private labels and national brands across online and offline channels. Management Decision, 50(10), 1772-1789. http://dx.doi.org/10.1108/00251741211279594

Raquel, C., Mónica, C., \& María, L. V. (2013). Situational variables in online versus offline channel choice. $\begin{array}{lllll}\text { Electronic Commerce } \quad \text { Research } & \text { 347-361. }\end{array}$ http://dx.doi.org/10.1016/j.elerap.2013.03.004

Seul, L., \& Brenda, J. C. (2011). Consumer complaint channel choice in online and offline purchases. International Journal of Consumer Studies.

Shuiqing, Y., Yaobin, L., Ling, Z., \& Sumeet, G. (2011). Empirical investigation of customers' channel extension behavior: Perceptions shift toward the online channel. Computers in Human Behavior, 27, 1688-1696. http://dx.doi.org/10.1016/j.chb.2011.02.007

Stephen, J. H. (2002). Product Experience Is Seductive. Journal of Consumer Research Inc., 29.

Tibert, V., \& Willemijn, V. D. (2009). Online purchase intentions: A multi-channel store image perspective. Information \& Management, 46, 77-82. http://dx.doi.org/10.1016/j.im.2008.12.001

Tobias, K., Andreas, K., \& Ina, K. (2012). Cannibalization or synergy? Consumers' channel selection in online- 
offline multichannel systems. Journal of Retailing and Consumer Services, 19, 186-194. http://dx.doi.org/10.1016/j.jretconser.2011.11.008

Tulay, G., \& Paul, D. (2010). Validating the search, experience, and credence product classification framework. Journal of Business Research, 63, 1079-1087. http://dx.doi.org/10.1016/j.jbusres.2008.12.011

Yaobin, L., Yu, Z. C., Bin, W., \& Shui, Q. Y. (2011). A study on factors that affect users' behavioral intention to transfer usage from the offline to the online channel. Computers in Human Behavior, 27, 355-364. http://dx.doi.org/10.1016/j.chb.2010.08.013

\section{Copyrights}

Copyright for this article is retained by the author(s), with first publication rights granted to the journal.

This is an open-access article distributed under the terms and conditions of the Creative Commons Attribution license (http://creativecommons.org/licenses/by/4.0/). 